\title{
Nākahi: The Matarahurahu Cult of the Snake
}

\section{Introduction}

While the great pressures of British colonialism that bore down on Māori society in the nineteenth century have been well documented, comparatively less attention has been devoted to the vigorous responses to these challenges mounted by some Māori communities in the form of peculiar religious innovations. The infant sects ${ }^{1}$ that arose in New Zealand during this period were of the sort Gibbon referred to as concoctions of corruption and error. They offered infirm and often fleeting faiths to a people whose traditional religious and spiritual precepts were in a state of turmoil as they collided with one of the world's most formidable and potent civilisations. Traditional Māori beliefs - derided by the missionaries as primitive prejudices - fell into decline, and instilled doubt in the minds of their former adherents. Yet, at the same time, not all Māori found the transition to the new religion a painless process. The cords binding them to their cherished 'old ways' could not be unravelled as easily as some missionaries and colonial officials might have hoped.

The result was a series of attempts by some Māori at a compromise, in which currents sourced from both the traditional and introduced beliefs were directed towards each other, and which sometimes curdled at their point of confluence. The strictures of either doctrine were loosened, and new dogmas were fabricated to accommodate the ambivalent requirements of their members.

These brief heretical eruptions - most common in regions where Māori had come into some contact with Christian 
missionaries - were generally short-lived. The majority did not survive the century, and those few that did managed to do so by reducing themselves to a much more pallid form. However, in the formative years of these sects, something of the spirit of discontent in many Māori communities in this era becomes apparent. And by observing the character, doctrines, and magnitude of some of these manifestations of religiosity, along with the zeal of their adherents, an insight is offered into the tension that accompanied the transformation of traditional Māori society that was crowded into just a few decades.

\section{Origins}

Of all the various Māori 'fusion' religions that flowered in the nineteenth century (possibly in excess of fifty) (Belich 1996: 220), Ringatū and Paimarire have jostled for the position of the most senior. Judith Binney, for example, cites Ringatū as '... the oldest of the surviving, scripturally based religions in Aotearoa' (1995: 1), with the qualification placed on 'surviving'. The missionary William Leonard Williams, writing in the nineteenth century, thought Ringatū was one of the earliest of such sects, and in common with most subsequent analyses, ascribed its creation to a need by its members to demonstrate defiance towards the vigorous advances of European sovereignty through the country. Its specific object, he concluded, 'seems to have been to detach the Maori people from Christianity and so relieve them from any scruples which the profession of Christianity might cause them to entertain with reference to some of the measures which their leaders might think fit to adopt in the prosecution of War against the Pakeha. Some of the Waikato people who had taken part in the fighting at Waitara also favoured this movement' (1930: 6465). The evidence to support the paternity of these sects can be sought by referring to their geographical spread, their success in breaching the divides between iwi, the existence of written elements of their faith, and observations made by 
outsiders of their doctrines and practices. And for both Ringatū and Paimarire, their links with so-called 'rebel' movements ensured that they received close scrutiny by European observers, thus bequeathing to subsequent generate ns a wealth of detail about them.

In contrast to the gratification of European curiosity that was obtained in the exploration of Ringatū and Paimarire, the roughly contemporaneous religion of members of the Matarahurahu hapū of Ngā Puhi - based in Kaikohe - and that of some of their ancestors going back at least to the early nineteenth century, shared comparatively few of the attributes of these other sects, and avoided arousing almost any interest from inquisitive Europeans. This religion was known by its followers as 'Nākahi' - meaning, literally, 'the snake'. After germinating in the 1830 s, and enjoying a brief flourish in the following decade, it was eventually confined to a few pockets in and around Kaikohe. It never spread outside the iwi, left virtually no written trace of its existence, and its services were conducted in secret on selected Saturdays, at night-time, in complete darkness. It is little wonder, then, that its greatest prominence in the literature on nineteenth century Māori religious movements is the fact of its virtual absence from serious examination. Nākahi, when it is even mentioned at all, tends to skirt around the periphery of studies in this area given a deferential glance by historians before they plunge into the detail of its southern successors. Not surprisingly, any effort to determine exactly when Nākahi emerged, and in the form it did, is undermined both by this general paucity of information, and the continued secrecy with which the sect has been sheathed since its inception.

Nākahi's roots already appeared to have sunk themselves deep in Northland well before the maddening rush of European peoples and culture flowed into the country (contrary to the assertions of some subsequent historians) (Bennet 2000: 1, Binney 1990). Indeed, Nākahi's earliest prophets - allegedly as far back as the 1720s - may have 
anticipated European intervention, rather than reacted to it, as the following prophesy from the early eighteenth century (possibly a bit too conveniently) suggests:

It will not be very long before I die, nor very long after I am dead, that a god will come on the crest of a wave, and ghosts (kehua) will be on his back. That god will be like the canoes in appearance, but he will be much larger, and he will sail over all the ocean. He will never be mistaken in his course over the ocean; he will sail away, and will not be seen by the people. After a long disappearance another god will appear, who will be like the former one. The first god will come by the aid of sails, but the latter by the aid of fire. (Smith 1910: 1112)

Whether this prophecy emerged from a member of a protoNākahi sect, as some Nākahi members later claimed (Rankin 2001), or whether (as is much more likely) it came from what can loosely be called the generic Māori religion, whose distinctive character was the subject of magnificent exaggeration generations later, cannot now be asserted with absolute certainty. However, there is no preponderance of evidence at all to suggest that traditional Māori religion - such as it was - was ever divided into specific denominations. Whatever slight differences may have existed in specific rites and rituals (and traces of these differences are few in quantity and anecdotal in nature) were more likely to be the product of regional variation than any deliberate intention to craft a separate sect.

\section{Formation}

Once the tributaries of Europe began to stream into New Zealand, however, and the diffusion of European values began to fashion aspects of Māori culture and society in its own image, many Māori communities enlisted the doctrines of their settler neighbours and in some cases, over the course of just a 
few years, clearly identifiable sects were born - each with their distinct doctrines and their spiritual leaders. The common explanations for the proliferation of these Māori religions in the mid-nineteenth century tend to be overly descriptive in most of the literature on the topic. However, when viewed from a more conceptual standpoint, the cause can be attributed to the circumstance of people of a primitive culture and those of a civilised culture living cheek to jowl. In Toynbee's famous reduction of the entire course of human history to a process of challenge and response, he introduced the notion of primitive societies mimicking some of the traits of the more civilised societies with which they come into contact. Drawing on his penchant for analogies, he proposed that:

An essential difference between civilizations and primitive societies as we know them .... is the direction taken by mimesis or imitation. Mimesis is a generic feature of all social life. Its operation can be observed both in primitive societies and in civilizations, in every social activity from the imitation of the style of filmstars by their humbler sisters upwards. It operates, however, in different directions in the two species of society. In primitive societies, as we know them, mimesis is directed towards the older generation and towards dead ancestors who stand, unseen but not unfelt, at the back of the living elders, reinforcing their prestige. In a society where mimesis is thus directed backward towards the past, custom rules and society remains static. On the other hand, in societies in process of civilization, mimesis is directed towards creative personalities who commanded a following because they are pioneers. In such societies, "the cake of custom," as Walter Bagehot called it in his Physics and Politics, is broken and society is in dynamic motion along a course of change and growth. (Toynbee 1939)

Toynbee's premise in this extract resonates with an element of truth. However, his explanation - relying on the premise that the primitive will slavishly emulate the civilised - 
imperfectly accounts for the creation of Māori fusion religions, and offers insufficient insight into the reason why these faiths exercised such an enduring hold on their members. The resilience of many of these sects, including Nākahi, was demonstrated in their continuation long after the colonisation and civilisation processes in New Zealand had been sapped of their initial force. Moreover, the related but superficially contradictory need to defy the civilised society at the same time as imitating it extends the explanation for the existence of these sects beyond Toynbee's two-dimensional analysis. As will be seen in the case of Nākahi, there was a political facet to some of these faiths that worked hand-in-hand with their more conventionally religious functions.

\section{Doctrine}

The canon of beliefs constructed by Nākahi's founders managed, with the benefit of considerable doctrinal manoeuvrability over the subsequent decades, to strike a convenient balance between offering a comprehensive religious code on the one hand, and allowing members a wide latitude in the definition of what it meant to be Nākahi on the other. Adherents could therefore claim to be Nākahi by citing their commitment to as many or as few parts of the sect's tenets that they felt was necessary.

What Nākahi stood for doctrinally was kept deliberately simple, and was dependent on a small cluster of provocative images which served to fortify and even invigorate its adherents, without having to defer to complex matters of dogma (of the sort that Māori witnessed had driven a wedge between Catholics and Protestants in the country from the 1830s). The sect's main beliefs were founded on prophesies supposedly from the eighteenth century (more likely the prophesies of tohunga in that period), which were later combined with fragments from the Old Testament that had filtered through to many Ngā Puhi in the early nineteenth 
century as a result of substantial missionary activity in the region.

At the core of this religion was the symbol of the snake taken from the book of Numbers - from which Nākahi derived its name. The relevant passage reverberates with the power of the relationship Moses had with God during a period when he was struggling to lead the Israelites in the desert. The imagery of ordinary people doubting their leader, and the need for that leader to reassert his power through symbols imbued with metaphysical significance had an obvious, and in a way almost theatrical appeal to many Nākahi followers, as well as anticipating what would grow to be a fundamental struggle for Māori leaders throughout the remainder of the century: to retain their authority in the face of rapid economic and social transformation. The extract from Numbers vividly portrayed the issues of doubt in a leader, and the role of religion in reasserting the leader's authority among his people:

They travelled from Mount Hor along the route to the Red Sea, to go around Edom. But the people grew impatient along the way; they spoke against God and against Moses, and said, "Why have you brought us up out of Egypt to die in the desert? There is no bread! There is no water! And we detest this miserable food!"

Then the Lord sent venomous snakes among them; they bit the people and many Israelites died. The people came to Moses and said, "We sinned when we spoke against the Lord and against you. Pray that the Lord will take the snakes away from us". So Moses prayed for the people.

The Lord said to Moses, "Make a snake and put it up on a pole; anyone who is bitten can look at it and live". So Moses made a bronze snake and put it up on a pole. Then when anyone was bitten by a snake and looked at the bronze snake he lived. (Bible 1978: Numbers 21-49) 
The image of the snake in the Garden of Eden also featured repeatedly in Nākahi teachings - admired because it was ' ... more crafty than any of the wild animals the Lord God had made' (Bible 1978, Genesis 3:1). Ironically, the counterpoint of this verse in the New Testament foretold of the fate of the snake: "The great dragon was hurled down - that ancient serpent called the devil, or Satan, who leads the whole world astray. He was hurled to the earth, and his angels with him' (Bible 1978, Revelations 12:9). The apparent selectivity of quoting from the Bible by Nākahi leaders probably accounts for this singular emphasis on the image of the snake as a positive image rather than a damned one, while the lax emphasis on precision in their points of doctrine avoided any derision that closer scrutiny of these beliefs may have brought.

The final biblical reference to the snake which Nākahi tohunga employed features in Exodus. In a similar vein to the Numbers extract, Moses was experiencing doubts over the power of his leadership, and the fact that some of the Israelites were disputing his ability to communicate with God. The subsequent exchange between God and Moses used the image of a snake to reaffirm the power God had vested in Moses:

The Lord said to him [Moses], "What is that in your hand?"

"A staff", he replied.

The Lord said, "Throw it on the ground".

Moses threw it on the ground and it became a snake, and he ran from it. The Lord said to him, "Reach out your hand and take it by the tail". So Moses reached out and took hold of the snake and it turned back into a staff in his hand. "This", said the Lord, "... is so that they may believe that the Lord ... has appeared to you". (Bible, Exodus 4: 2-5)

Nākahi was not exclusively a sect which sourced its doctrine from the Old Testament however. Use was made use of Christ's words in John - again referring to the image of a snake: 'Just as Moses lifted up the snake in the desert, so the 
Son of Man must be lifted up, that everyone who believes in him may have eternal life' (Bible 1978, John 3: 14-15). Again though, the choice of texts which the sect's leaders used was disorganised, and seems to have been founded on the sole criterion that a snake was mentioned in the chosen passages.

However, according to the late Matarahurahu kaumātua, Graham Rankin (2001), Nākahi's appropriation of such texts made it a religion tailored specifically for a political and military leadership class within Ngā Puhi. Indeed, its character was as much, if not more, temporal than spiritual, with a significant stress maintained on the importance of power, effective rule, and the requirement that people have absolute faith in their leaders. The image of the snake was popular because it combined elements of danger, cunning, persistence, wisdom, and most importantly, defiance. These were traits which he suggested were esteemed by Māori in the preEuropean period, and which could be adopted by followers of the faith as a means of preserving some of the political strength of the hapu and iwi. In addition, they contributed to a doctrine which was simple to profess and which offered a specifically Ngā Puhi counterpoint to the Christian denominations that the missionaries were promulgating at the time (Rankin 2001). Given this assessment, it is possible to interpret the emergence of Nākahi as part of the nascent Māori political revival in parts of Northland to the same extent that it was solely a religious development. Certainly, events in the following decade showed how closely the political and ritual aspects of Nākahi had grown together.

\section{Papahurihia}

In the 1830s, Nākahi found its Mohammed - the prophet leader who would take the obscure and disordered doctrinal fragments of the old version of the sect, and re-shape them into a new religion. This person was the Ngā Puhi tohunga Papahurihia (who later renamed himself Te Atua Wera - the 
fire god). Probably born in the first decade of the nineteenth century, he initially rose to prominence and built a committed following through affiliating himself with the matakite tohunga: those who could prophesise, communicate with the dead, or act as mouthpieces for the dead. The senior Church Missionary Society missionary in the country during the 1830s, Henry Williams, mistakenly believed that Papahurihia was the founder of Nākahi, as opposed to its chief exponent (Rogers 1961: 378), and was predictably dismissive of the cult:

Soon after the establishment of the Christian Mission at Hokianga, the work extended to Waihou, Mangamuka, Waipa, and other places of the Hokianga. Native itinerant teachers carried the word of peace to Taranaki, and its neighbourhood, while others laboured in the more immediate localities of the Mangungu mission station. Among these were, Wiremu Patene, Rihimona, and Matiu, who, on the occasion of their holding a religious meeting at Mangamuka, were fired upon by the Chief Kaitoke and his adherents, who were under the influence of a noted Maori ventriloquist named Papahurihia, who held nightly meetings, at which a large concourse of Maoris attended for the purpose, it was alleged, of holding intercourse with their departed friends, the ventriloquist being the medium of communication. This Maori necromancer had sent to his Mangamuka disciples a gun with certain hieroglyphics marked on it, the sanguinary meaning of which, if not fully understood by Kaitoke, was to be explained by the bearer of the weapon. While divine service was being proceeded with, the three bullets intended for Wi Patene, passed through his garments, Rihimona was mortally wounded, and Matiu killed, while holding the word of life in his hands. (David 1876: 27-28)

The merchant Joel Polack, who came across this sect in 1837, offered a more detached assessment of its origins: 'A new religion was introduced near the North Cape, about the 
same time, by whom it was invented it is impossible to say; the creed consisted in the belief of the Creator, whose Prophet was called Papahurihia, a native residing among the tribes at that place. The day of rest was on the Saturday, in distinction to the Sunday of the Christian natives' (Polack Vol. 2 1840: 237).

Papahurihia commenced his vocation in the early or mid1830s in Te Puna, which was also the site of a moderately successful Church Missionary Society station in this period. The close proximity to pioneering missionaries provided Papahurihia with an additional, Christian dimension to the traditional tohunga role he had been exercising up until that time. He stood out from other tohunga, however, because he was intent on reconstructing his traditional beliefs in a manner that accommodated European Christian elements, and because he was personally aiming to develop the Nākahi sect into a religion specifically tailored for cultivating Ngā Puhi political power (Rankin 2001).

By the close of the 1830s, Papahurihia's reputation was widespread in Northland, and was especially pronounced in the Bay of Islands and its immediate hinterland. Yet, just at the point when the popular appeal of the sect seemed to promise an extended following, the doctrine Papahurihia was developing for Nākahi began to mutate. In the preceding decade, it had taken on the form almost of a Māori variant of Christianity, but by the early 1840 s, one of the identifying features of this greatly revised version of Nākahi's doctrine was its belligerently anti-Christian orientation. Membership of the sect from this time was more strongly an act of protest, not so much at the missionaries or even Christianity per se, but at what they stood for, and the visible signs of encroachment into Māori culture, politics, and society that the European presence generally represented. The fact that Nākahi was practised in secrecy allowed the protest to persist, yet without the direct chastisement or even awareness of those at whom the protest was directed (Rankin 2001). 
And when Nākahi activity did emerge from behind its selfimposed concealment and show itself to the outside world, the reaction from Europeans was typically unfavourable. This ought not to be surprising in itself, but what is notable is that the outlines of the religion that were sketched by European onlookers frequently highlighted a quarrelsome spirit among its adherents:

The least foreseen causes of wars, has broken out within the last three years, nothing less than a schismatic difference between the natives in their religious opinions, between those who have placed themselves under the banners of the Wesleyan Missionaries, and some new idolators, who term themselves disciples of Papahurihia. The sabbath is fixed by these modern luminaries on the seventh day or Saturday. This novel credenda consists in a God of fire or Wero being president, and he has sent forth a prophet to work miracles, teach the people that the missionaries are cheats, and other similar silly tales.

This fiction, it is said, was invented by the master of a whale ship, which if true, he must have been contemptibly wicked, to attempt to delude these people from the knowledge of a true God. That the prophet is a New Zealander there can be no mistake, as his affections are said to be equally affected towards discussing food, as polemics. (Polack Vol. 2 1838: 6263)

It may have been a cult borne of a conjuring trick, as this preceding extract written by Polack alleges, but Nākahi invigorated its existing members and attracted new followers so much so that by the mid-1830s, it was drawing the attention of local missionaries who perceived its mounting popularity as a direct threat to their own endeavours.

It may here be observed, that various means have been used to thwart the designs of the Missionaries; and, among other artifices, one was adopted, which would have had the effect of confusing the opinions of the Natives, in respect to the 
Lord's Day, had the scheme of the impostor succeeded. The particular instance to which I refer, had in it such plain marks of Satanic ingenuity and malignity, that I am induced to digress a little, in order to relate it. A Native had been for some time on board ship, and had taken several voyages with a man acquainted with the art of ventriloquism. The thought occurred to this person, who commanded the ship, that if he could teach this uninstructed man the art, it might, on his return to New Zealand, be turned to some account, and frustrate the plans of the Missionaries for the conversion of the people.

He was aware that it would excite surprise in the NewZealand mind, and apprehended that, if properly used, it would awaken their curiosity and fix their superstition: he therefore persuaded this young man to give out, that he was either a god, or a teacher sent from God; and then to prove his mission by throwing his voice into inanimate substances, making it appear that the very stones bore testimony to the truth of his statements: and then to address the people in confirmation of what he was teaching. The young man adopted the plan gave to his god the name of Papahurihia announced the changing of the Sabbath-day from Sunday to Saturday and succeeded in gaining the attention of many who acknowledged him as a teacher: but at the same time, he himself declared that the God whom we worshipped was the great and the Holy God, and that the religion of Jesus Christ, which we taught, was the true religion; only, that we were wrong in the day on which we more particularly required the people to worship God. In the midst of all this, some very strange things were asserted, which, notwithstanding the wonderful display of his ventriloquism, convinced the Natives, almost universally, that he must be an impostor. We thought the better way was, to watch its progress in silence, lest by much interference we should give a notoriety to the subject; convinced, at the same time, that, as it was not of God, it must soon come to nought. (Yate 1835: 221-222) 
By the mid-1840s, Nākahi was returning the favour. Particular contempt was being directed at the Protestant missionaries by Papahurihia and some of his senior followers as the struggle by Nākahi against Christianity descended into a slagging match. While the Protestants would burn in the fire with Satan, Papahurihia's followers - he triumphantly asserted - would go to a place where they would '... enjoy unending light'. Everything would be '... found in plenty, flour, sugar, guns, ships; there too murder and sensual pleasure reign' (Servant 1990). The missionaries were the enemy in doctrine, but in practice, Nākahi never directly threatened them. This is explicable in part because Nākahi needed a tangible enemy to bolster the solidarity of its adherent, and because as much as the sect's leaders would have been loath to admit it, Christianity was the source of most of their doctrine, and so the artery that connected them with the missionaries needed to be preserved.

There was also a prophetic side to Papahurihia's mission that he used to great effect. Like countless other pretenders before him throughout the Christian world, he employed a Biblical extract to suggest that his presence and purpose had been foretold. This gave him an extra veneer of religious authenticity and authority among his disciples. The relevant section from the book of Exodus that he quoted stated:

See, I am sending an angel ahead of you to guard you along the way and to bring you to the place I have prepared. Pay attention to him and listen to what he says. Do not rebel against him; he will not forgive your rebellion, since my Name is in him.

If you listen carefully to what he says and do all that I say, I will be an enemy to your enemies and will oppose those who oppose you.

My angel will go ahead of you and bring you into the land of the Amorites, Hittites, Perizzites, Canaanites, Hivites and Jebusites, and I will wipe them out. 
Do not bow down before their gods or worship them or follow their practices. You must demolish them and break their sacred stones to pieces. (Bible, Exodus 23: 20-24)

The rhetoric of defiance and destruction tantalised the Nākahi congregations and emboldened their commitment to defend their political and cultural rights against whatever threats they saw. Implicitly, this meant that they had to place their faith in Papahurihia as the man who restored their confidence and roused their defiance.

The height of Papahurihia's influence and fame occurred in 1845, when the Ngā Puhi warrior and rangatira, Hone Heke, took him on as his personal tohunga. Heke, who was also a follower of Nākahi, put great faith in Papahurihia's pronouncements, particularly on the progress of Heke's war against the British in the mid-1840s (Manning 1877: 93). It was during this period that Nākahi followers developed an almost pathological hatred of Christianity.

The tepid phase of protest against Christianity in the early 1840s - based on the appearance of Christianity as a manifestation of European colonisation - had transformed into a doctrinal hatred in which the teachings of Christ were vilified solely because they were the teachings of Christ. Yet, in the maelstrom of this contempt for the faith of the New Testament, Papahurihia was still unable to completely separate himself from Christianity. To those of Heke's troops who had converted to Christianity, he counselled: 'You who pray to the god of the missionaries, continue to do so, and in your praying see you make no mistakes. Fight and pray ... abstain from human flesh, lest the European god should be angry' (Manning 1877: 95).

Following the inconclusive outcome of Heke's war against the Crown, Papahurihia entered a quieter phase of his career, and for someone who professed severe contempt for Christianity, was regularly in contact with several missionaries who visited him at his base at Ōmanaia, including John 
Webster, John Warren, Thomas Buddle, and the Catholic Maxime Petit. The work of the Protestant missionaries in particular in this part of Northland was under way with real vigour, and conversions of Māori to Christianity were occurring at a steady rate. However, from 1846, Papahurihia reined in his formerly outlandish denunciations of the missionaries in the region. Nākahi appeared to be undergoing yet another revolution in its relationship with Christianity. The critical turning point came in 1856, when Papahurihia himself was converted to Christianity by Āperahama Taonui, and took on the name Penetana. The baptism was conducted by the Wesleyan missionary Thomas Biddle (Binney 1990) with whom Papahurihia had been in frequent contact.

Still though, a slender seam of dissent occasionally ran through Papahurihia's thoughts. In 1869, he baptised Hōne Heke Ngāpua (Hone Heke's grand-nephew and a future Member of Parliament) into the Christian faith, although deliberately utilising the outward vestiges of the Nākahi religion to hark back to the time when he was Hone Heke's personal tohunga. He offered intermittent prophecies on certain major issues of the day, such as the wars of the 1860 s, and following his burial in November 1875, a memorial stone placed on his grave on behalf of the Government (op. cit.) was reported to have turned by itself to face north, where Ngā Puhi tradition claimed the spirits of the dead departed to the afterlife (Rankin 2001).

As a political or even religious force, Nākahi seems to have exhausted its energies by the late 1860s. Writing on another Māori sect - the Hauhau movement - Edward Marsh Williams, who was the Resident Magistrate at Waimate, described the situation as he saw it in 1868 :

Ngapuhi ridicule the very name, and declare they will never tolerate the system within their district. They compare it to one of a similar character called the "Karakia Ngakahi" (serpent worship) introduced some years ago by Papahurihia, and which for a time 
engrossed the attention of many among themselves, but which gradually died out, although Papahurihia continues to be respected as a high authority, and his "Atua" often consulted. The man is a ventriloquist, and by throwing his voice induces the belief that their questions are answered by the god they invoke. (Smithyman 1997: 188)

\section{Decline}

During the 1880s, the influence of the Anglican Church in Northland reached its zenith, and several of the chiefs in the region - men like Rēnata Tangata, Hare Peka Taua, Matiu Kapa, Hone Papahia, and Rupene Paerata (Williams 1968) were given clerical posts in the Church. Hōne Heke's nephew Hōne Ngāpua - was by virtue of whakapapa the highest ranked in this cohort, and shared some of his relation's desire for recognition. Moreover, even though he was also a member of the Nākahi sect, Hōne Ngāpua was prepared to forego his membership if it meant getting a position in the Anglican Church. However, he stated he would not be satisfied with being a lay cleric. Instead, he insisted that he be appointed to the rank of bishop. Naturally, Church officials politely declined his demand, whereafter he reverted to his Nākahi roots with renewed intensity. For a few years in the late 1880s, Hōne Ngāpua would ring a bell outside his house every Sunday morning as most of the town's residents made their way to church. This bell was to signify that he was holding a Nākahi service at the same time, in defiance of the Anglican Church that he felt had rejected him (Moon 2006: 64-65). Once again, the survival of Nākahi was based less on what it stood for as what it was opposed to.

By the end of the nineteenth century, Nākahi no longer was mentioned as a current sect by anyone writing about contemporary Northland. However, although its membership crumbled away probably to fewer than fifty followers by the 1880s - perhaps mirroring the demise of Māori as a political 
force in the country - its surviving devotees clung (with descending degrees of commitment) to its doctrine and practices. Even into the middle of the twentieth century, followers still pursued their interest in the Nākahi faith, but more in deference to their ancestors' adherence to the sect than out of any determined commitment to its doctrine (Rankin 2001). Its conversion in this manner - into a preserved relic of nineteenth-century Māori religious experimentation - represented the end of the sect as a force for political activism and as an enduring alternative to Christianity.

\section{Bibliography}

Belich, J., 1996. Making Peoples: A History of New Zealand from Polynesian Settlement to the End of the Nineteenth Century, Auckland, Penguin.

Bennett, R., 2000. The Declaration of Independence: An Analysis, Auckland, publisher not stated.

Bible, New International Version, 1978. New York, Zondervan.

Binney, J., 'Ancestral Voices: Maori Prophet Leaders', in Sinclair, K. (ed.), 1990. The Oxford Illustrated History of New Zealand, Auckland, Oxford University Press.

Binney, J., 1995. Redemption Songs: A Life of Te Kooti Arikirangi Te Turuki, Auckland, Bridget Williams Books.

Cowan, J., 1930. The Maori Yesterday and Today, Christchurch, 1930, Whitcombe and Tombs.

David, C. O., 1876. The Life and Times of Patuone, the Celebrated Ngapuhi Chief, Auckland, J. H. Field, Steam Prinitng Office.

Kohere, R. T., 1949 The Story of a Maori Chief, Wellington, A. H. and A. W. Reed.

Maning, F. E., 1877. Old New Zealand; a tale of the good old times and A history of the war in the north told by an old chief of the Ngapuhi tribe, Auckland, Creighton and Scales. 
Moon, P., 2006. Ngapua: The Political Life of Hone Heke Ngapua, MHR, Auckland, David Ling Publishing.

Polack, J. S., 1838. New Zealand : being a narrative of travels and adventures : during a residence in that country between the years 1831 and 1837, vol. 2, London, Richard Bentley, New Burlington Street.

Polack, J. S., 1840. Manners and customs of the New Zealanders : with notes corroborative of their habits, usages, etc., and remarks to intending emigrants, with numerous cuts drawn on wood, vol. 2, London, James Madden and Co.

Rankin, G., 21 February 2001. Interview in Kaikohe.

Rogers, L. M. (ed.), 1961. The Early Journals of Henry Williams: Senior Missionary in New Zealand of the Church Missionary Society: 1826 1840, Christchurch, Pegasus.

Servant, L. C. cited in J. Binney, 1990. 'Papahuirhia', in Dictionary of New Zealand Biography, Volume One, 1769-1869, Wellington, Department of Internal Affairs.

Smith, S. P., 1910. Maori Wars of the Nineteenth Century: The Struggle of the Northern Against the Southern Maori Tribes Prior to the Colonisation of New Zealand in 1840, Christchurch, Whitcombe and Tombs.

Smithyman, K., 1997. Atua Wera, Auckland, Auckland University Press.

Toynbee, A. J., 1939. A Study of History, Oxford, Oxford University Press.

Williams, F. W., 1939. Through Ninety Years: 1826-1916, Life and Work Among the Maoris in New Zealand. Notes of the Lives of William and William Leonard Williams, First and Third Bishops of Waiapu, Auckland, Whitcombe and Tombs.

Williams, P., March 1968, unpublished MS, Auckland, private collection.

Yate, W., 1835. An account of New Zealand and of the formation and progress of the Church Missionary Society's mission in the northern island, London, R. B. Seeley and W. Burnside.

The terms 'sect', 'cult', 'religion', and 'faith' are used interchangeably in this work. 